\title{
Developing interactional repertoires in the classroom through dynamic strategic interactio scenarios
}

\author{
Rémi A. van Compernolle \\ vancomp@cmu.edu \\ Nuria Ballesteros Soria \\ nballest@andrew.cmu.edu \\ Department of Modern Languages \\ Carnegie Mellon University
}

\begin{abstract}
In this article, we report on the implementation of Dynamic Strategic Interaction Scenario tasks as one approach to developing L2 learners' interactional repertoires. The tasks involve pre-task planning, a performance, and immediate feedback during a whole-class debriefing discussion. We focus specifically on the appropriation of turn allocation devices within a single class meeting in which three small groups performed the same scenario. We show how the first group's performance prompted a focus on turn allocation during their debriefing, and how the subsequent groups were able to build on the feedback in their own performances. We discuss our findings and their implications for research and pedagogy along three dimensions: 1) the role of feedback as mediation in the debriefing discussions; 2) the contribution of task repetition from a group-as-collective perspective; and 3) the documentation of interactional repertoire development over time.
\end{abstract}

Keywords: Interactional repertoires; Interactional competence; Dynamic strategic interaction scenarios; Turn allocation; Spanish as a second or foreign language

\section{Resumen}

Este este artículo se presenta la implementación de escenarios de interacción estratégica y dinámica como un método para promover el desarrollo de los recursos de interacción entre discentes de lenguas extranjeras y de segundas lenguas. Las tareas constan de una fase de planificación y una de representación, seguidas de una discusión y puesta en común en asamblea en la que se ofrece retroalimentación inmediata. El presente artículo se centra especialmente en la apropiación de recursos para la cesión 
del turno de habla durante una clase en la que tres pequeños grupos representan el mismo escenario. Se muestra cómo la representación del escenario por parte del primer grupo motiva una conversación sobre la cesión del turno de habla durante la puesta en común y cómo el resto de grupos incorpora la retroalimentación en sus respectivos escenarios. Los resultados y las implicaciones pedagógicas y de investigación se abordan en relación con tres temas: 1) el papel mediador de la retroalimentación durante las discusiones de las puestas en común; 2) las aportaciones de la repetición de tareas desde una perspectiva grupal y colectiva y 3 ) el estudio del desarrollo del repertorio de recursos de interacción a lo largo de la sesión.

Palabras clave: repertorios de recursos de interacción; competencia interaccional; escenarios de interacción estratégica y dinámica; cesión del turno de habla; español como segunda lengua o como lengua extranjera

\section{Introduction}

Developing speaking abilities is an important goal for second and foreign language (L2 for simplicity) education. Informed by models of communicative competence (Bachmann, 1990; Canale \& Swain, 1980; Celce-Murcia, 2007; Celce-Murcia, Dörynei, \& Thurrell, 1995), pedagogical arrangements aimed at developing learners' speaking abilities have traditionally focused on the learner's capacity to generate and understand spoken language as an individual competence. However, more recent approaches to understanding L2 speaking in terms of interactional competence (IC) (Hall, Hellermann, \& Pekarek Doehler, 2011; Salaberry \& Kunitz, 2019; Waring, 2018) and the deployment of interactional repertoires (Hall, 2018) have refocused attention on the way in which speaking is coproduced between interlocutors. This perspective has broadened the purview of speaking development to include not only linguistic features of communication (e.g., grammar, lexis, speech acts) but more importantly the interactive practices that underly turn-taking systems, conversational repair, and action sequencing.

In this article, we report findings from an initial attempt at supporting the development of L2 interactional repertoires through a series of dynamic strategic interaction scenario (DSIS) tasks (van Compernolle, 2014a, 2014b, 2018) that were integrated into an existing elementary-level Spanish course at a US university. The DSIS tasks were performed by multiple small groups in front of the class, and feedback on language use and interactional strategies was provided by the teacher and other students after each performance. Our focus in the present article is on the microgenetic development of turn allocation practices that occurred in one class meeting, where each group was able to build on the performances of and feedback given to prior groups. 
A study of L2 vocabulary acquisition under incidental and intentional conditions

\section{Background}

\subsection{Interactional competence and interactional repertoires in L2 learning}

The notion of interactional competence as a pedagogical target in L2 settings dates back at least to Kramsch's (1986) critical appraisal of the proficiency movement in language teaching and testing circles. Kramsch points out that proficiency models, grounded as they are in individualistic conceptions of communicative competence (Canale \& Swain, 1980), assume that "language teaching and learning are inputoutput processes, guided by a linear acquisition of grammatical structures and that the major criterion of accuracy is grammar correction" (p. 370). This assumption, she argues, ignores the fact that successful communication involves an interaction between interlocutors as they negotiate the meaning and significance of language-in-use. While more recent models of communicative competence (Celce-Murcia, 2007) and speaking proficiency (ACTFL, 2012) have recognized the role of such interactive phenomena as turn-taking and meaning negotiation, they remain centered around the individual rather than the processes and outcomes of communication between people.

In the 1990s and early 2000s, research informed by linguistic anthropology and conversation analysis (e.g., Hall, 1993, 1995; He \& Young, 1998; Young, 2008) began to take seriously the idea that an L2 user's competence during communication was an interactive phenomenon. In this line of inquiry, interactional competence is not something acquired and possessed by the individual; instead, it is what becomes relevant and available in one's interactions with others. This is to say that competence is distributed across interlocutors. It is contingent not only on lexicogrammatical forms but on shared understandings of the context as well as shared orientations to relevant next actions in interactive discourse.

As research in this domain has gained attention among L2 researchers, however, there has been a conflation of two leading concepts, as Hall (2018) points out. On one hand, interactional competence has been used to refer to the "basic interaction infrastructure of human sociality" (p. 28), a notion derived from conversation analysis. On the other hand, the term has been used to describe "variability of individual knowledge within and across social groups" (p. 28), which is the focus of work in linguistic anthropology. While both traditions have come to inform interactional competence scholarship, Hall argues that we need an alternative concept to describe the types of interactive practices that L2 learners appropriate in their developmentinteractional repertoires. This terminology underscores the idea that interactional competence is a kind of universal underlying infrastructure for human sociality whereas in L2 development the task for learners is to appropriate a diverse and context-sensitive 
repertoire of interactive resources for engaging in communicative activity. The resources that make up a learner's interactional repertoire constitute the objects of analysis in this line of inquiry.

Research on instructional arrangements specifically designed to develop and expand learners' interactional repertoires is just now emerging (e.g., BarrajaRohan, 2011; Kunitz \& Yeh, 2019; Lilja \& Piirainen-Marsh, 2019; Waring, 2019). Although the contexts of instruction, languages, and foci vary across these studies, three common threads run through them. First, the focus of pedagogy must shift from lexicogrammatical forms to interactive practices, especially with regard to turn taking strategies. Second, awareness of interactive practices should be fostered so that learners can consciously attend to and reflect on the appropriateness of their interactive practices. Third, learners need opportunities to participate in interactions where they can enact their developing interactive repertoires. Thus far, research has predominately focused on organizing pedagogical arrangements around awarenessraising tasks, following Barraja-Rohan's (2011) suggestion that language learners become, to some extent at least, conversation analysts in their own right. This means introducing some of the central concepts of turn-taking from the conversation analysis (CA) literature (Sacks, Schegloff, \& Jefferson, 1974) and having learners analyze speech samples, such as recordings and transcriptions of native speaker speech events. To our knowledge, no research has examined the integration of speaking tasks specifically designed to develop both awareness of interactional practices and learner IC in a classroom context.

\subsection{Dynamic strategic interaction scenarios}

Dynamic strategic interaction scenarios (DSISs) were originally developed as part of a Vygotskian approach to teaching pragmatics through concept-based instruction as a means of focusing learners on both meaning and form in communicative tasks (van Compernolle, 2014a, 2014b, 2018). The tasks draw on DiPietro's (1987) strategic interaction approach to L2 instruction that involves three stages: (i) a rehearsal, where learners can reflect on and plan appropriate language for (ii) a performance, during which the scenario is executed, which is followed by (iii) a debriefing in which the teacher and other students can provide feedback. In van Compernolle (2014a, 2014b), DSISs were carried out in one-on-one tutoring sessions during which the tutor was able to provide assistance, or mediation, during the performance following insights from dynamic assessment (Poehner, 2008). In this way, the tasks played a dual role as assessments of learner abilities and instructional interventions. As discussed in van Compernolle (2018), however, an extension to the classroom would involve whole group feedback as mediation during the debriefing stage. The idea would be to engage 
in a group dynamic assessment (Poehner, 2009) in which small groups of students could build on the performances of and feedback provided to previous groups.

\subsection{Turn allocation}

A central focus of pedagogical arrangement designed to enhancing L2 interactional repertoires is the turn-taking system (Barraja-Rohan, 2011). Drawing on conversation analytic research starting in the 1970s (Sacks et al., 1974; see Schegloff, 2007; Sidnell, 2011 for more recent work), the claim is that L2 IC is grounded in the ability to negotiate turns-at-talk. One important dimension of turn-taking is how turns are allocated (i.e., selecting the next speaker). As outlined in Sacks et al. (1974), there are three hierarchically organized options for allocating next turns. First, the current speaker may select the next speaker explicitly (e.g., by name) or implicitly (e.g., by gaze, gesture, or context and content of speech), who in turn has both the right and obligation to take the floor. Second, if no next speaker is selected by the current speaker, other participants can selfselect (e.g., to respond to an open question or to proffer a new topic if the preceding turn closes a prior sequence). Third, the current speaker may elect to continue his or her turn if no other participant self-selects as next speaker.

The importance of turn-allocation mechanisms becomes especially clear in interactions involving three or more participants because no single currently nonspeaking party can presume to be the next speaker. In other words, since the next speaker could be any one of two or more non-speaking participants, there is the potential for competition in being allocated or self-selecting to take up the next turn. As Sacks et al. (1974) write:

a current non-speaker, if interested in speaking next, will be under constraint to self-select at first possible transition point, and at each successive such point. Furthermore, if a current speaker is interested in choosing among potential next speakers, he will be under constraint to accomplish the selection before first possible transition place ... , lest an undesired current non-speaker self-select at that point. (Sacks et al., 1974, p. 713)

Thus, learning to allocate turns to a desired next speaker and to self-select as next speaker is key to developing the capacity to manage turn-taking in interaction.

Following Hall's (2018) proposal to shift toward thinking in terms of interaction repertoires, we conceptualize turn allocation itself as part of the underlying infrastructure of competent interaction. By contrast, the appropriation of specific turn allocation devices-the actual practices by which turn allocation is achieved- 
constitutes the development of one's interactional repertoire. Our interest as analysts, then, is documenting the expansion of learners' repertoires for allocating next turns.

\section{Methods}

\subsection{Context and participants}

The data we draw from for this article were collected as part of a larger project examining speaking development in an elementary-level US university Spanish classroom. The class was audio/videorecorded throughout the academic term, typically two times per week starting in week 4 of the term, resulting in approximately 18 hours of data. The class was taught by the second author of this paper, a native speaker of Spanish. The first author supervised the study and collected the data. There were 13 university students enrolled in the class, all of whom consented to participate in the study.

\subsection{Implementation of DSIS tasks}

DSIS tasks were integrated into instruction as a way of complementing the existing curriculum, with an eye toward enhancing the development of learners' interactional repertoires. In other words, DSISs were designed to follow and build on the themes, grammar, and vocabulary presented in the textbook. The DSISs were assigned to small groups, typically 2-3 students, each of whom had a different role to perform in the scenario and conflicting agendas that they would need to negotiate. Following DiPietro (1987), while all students understood the general context of the scenario, they were not made aware of the specific details of each other's roles.

DSISs were completed in three stages following van Compernolle's (2018) recommendations for the classroom. In the first stage, students were provided with a description of the scenario and information about the role they would play. As homework, they were instructed to reflect on the language and interactional strategies that would be useful in the scenario (see Appendices A, B, and C). In the subsequent class meeting, the students met briefly with students from other groups who had been assigned the same role so that they could share and compare their homework, strategize about useful language and interactional resources, and so on. The second stage was the performance. Each group performed the scenario in front of the class, which lasted approximately 3-4 minutes each. The third stage was the debriefing or feedback stage. After each group's performance, the instructor and students provided an evaluation of the performance and offered suggestions for improvement. In other 
words, feedback (stage 3) way layered between each group's performance (stage 2) so that each subsequent group had the chance to benefit from the feedback provided to prior groups as a form of cumulative group dynamic assessment (Poehner, 2009).

\subsection{Analytic procedures}

For this article, we have decided to illustrate the potential benefits of cumulative feedback on DSIS performances during a single class period. To this end, we began our analysis by reviewing the audio-/video-recordings made during DSIS performances ( $\mathrm{n}$ $=3$ ) and identifying possible foci of interest (e.g., emergence of learning opportunities, feedback strategies). The current analysis centers on the emergence of learning opportunities around turn allocation that emerged during the second DSIS task. We transcribed the performances and feedback discussions. Transcription conventions are provided in Appendix D. We then identified the interactive practices used for allocating next turns in each of the performances as well as the practices, suggestions, and so on that were discussed in the feedback stages. In doing so, we were able to reconstruct the microgenetic development of turn allocation practices across multiple groups during a single class meeting. In the interest of space, we have limited our analysis to the first three group performances and feedback stages.

\section{Findings and analysis}

We report our findings in three parts. First, we present Group 1's scenario performance and feedback stages, focusing on turn allocation practices, which emerged as a topic in the feedback discussion. Second, we show Group 2's scenario performance, in which the participants incorporated some of the feedback from the prior group's performance, as well as their feedback stage in which the students and teacher expanded their discussion of turn allocation practices. Third, we analyze Group 3's performance to show how they built on the prior two groups' performances and the class's feedback.

\subsection{The emergence of turn allocation as an instructional focus}

Excerpt 1 shows the first minute or so of Group 1's performance (Greg, Frank, and Tianyu; all names are pseudonyms). Greg opens the interaction by initiating a greeting sequence that Frank and Tianyu both participate in (lines 1-7). At line 8, then, Greg responds to Frank's prior turn, más o menos (line 7), with a follow up question, ¿Por qué?, thus allocating the next turn to Frank, who goes on to explain that he is suffering from allergies. The next 9 turns (lines 9-22) are taken by Greg and 
Frank, who expand the discussion of allergies to include making plans to go shopping and to go outside. Note that next speaker selection is achieved implicitly through context (Sacks et al., 1974): Greg and Frank are engaged in a series of question-answer sequences about allergies and shopping, which makes them the only relevant speakers, to the exclusion of Tianyu, who self-selects as next speaker in line 23. Her self-selection as next speaker is made possible only after Frank ends his turn (line 22) and looks down at his watch, which opens up the interactional space for a third party to take the floor. It is worth noting here that Tianyu's self-selection as next speaker comes at a point in the interaction where the discussion of allergies appears to be closing, and she uses this opportunity to proffer a new topic that is relevant to her speakership: the end of the semester and her need to finish her school work.

\section{Excerpt 1}

1 Greg ¡Hola, mis amigos!

Hi friends!

2 Frank ¡Hola!

Hi!

3 Tianyu ¡Hola! ((saluda a Frank con la mano))

Hi! ((waves at Frank))

4 Greg ¿Cómo estáis?

How are you guys?

5 Tianyu Bien, ¿y tú? ((se dirige a Greg))

Good. How about yourself? ((turns to Greg))

6 Greg Tengo [frío.

$$
\text { I'm[cold. }
$$

7 Frank [Más o menos. ((mueve la cabeza hacia los lados))

[So, so. ((shakes his head)) 
8 Greg ¿Por qué?

Why?

9 Frank Em + es mucho polen outside + fuera.

$U m+$ there is a lot of polen + outside.

10 Greg Yo también + más o menos? + porque necesito

Me too + so, so? + because I need

11

nueva ropa por la primavera.

new clothes for the Spring.

12 Frank Ah, sí, sí ((asiente con la cabeza)), em +,

Oh, yeah ((nods)), um +,

¿quiero comprar?

do you want to go shopping?

14 Greg Em + ¿en el centro de comercial?

$U m+$ at the mall?

15 Frank Em pero yo tengo alergias y no + quiero + ir afuera.

Um but I have allergies and I don't + want to + go outside.

16 Greg ¿Por qué no?

Why not?

17 Frank Tengo ALERGIAS + mucho ((tose)).

I have ALLERGIES + I a lot ((coughs).

18 Greg Lo siento + em + caminar en el afuera es

I'm sorry $+u m+$ walking outside is 
mucho bueno por tu corazón y su + em alma.

very good for your heart and your + um soul.

20 Frank

Pero yo quiero + em comprar en el Internet ((risas))

But I want + um to buy things online ((laughs))

21

+ muy fácil ((levanta el dedo pulgar))

+ very easy $(($ thumbs up))

22

((mira su reloj))

((looks down at his watch))

23 Tianyu Pero + em + es la final del semestre es + em +

$B u t+u m+$ the end of the semester $+u m+i s$

es próximo, ++ em así necesito com com completar

close, ++ um so I need to fin fin finish

los trabajos de universidad.

my papers for school.

The remainder of the scenario unfolded in a similar way: Frank and Greg took 16 of the next 19 turns. Tianyu's three turns were all self-selections at transition points. In other words, neither Frank nor Fred allocated any turns to her through explicit or implicit means, which was noted during the feedback stage (excerpt 2). In this exchange, the teacher asks the class for constructive feedback on ways to improve the scenario. In response, Sophie notes that Tianyu seemed to be left out of the scenario performance (lines 4-6). The teacher confirms the observation (lines 7-8) and asks Tianyu to account for it (line 9). The reason, according to Tianyu, was that she was unable to "find an opportunity to join in the conversation" (line 10). Her response then prompts the teacher to solicit recommendations from the class on how to "overcome" (line 13) the problem. Jane offers a general strategy ("ask her what she thinks"; lines 14, 16), and following the teacher's prompt to provide Spanish resources for doing so (line 20), Sophie and Emmitt offer two turn allocation devices: the tag question iy tú? (line 21) and the Wh-question ¿Qué creas tú? (line 23). 


\section{Excerpt 2}

1 Teacher Sophie?

2 Sophie To improve?

3 Teacher Yeah.

4 Sophie I think one of the group members seems to be left out.

5 Teacher Sorry, one of the +? ((asking for repetition))

6 Sophie Group members + Tianyu.

7 Teacher Okay, yeah. Tianyu stepped in and joined the

$8 \quad$ conversation a bit late.

$9 \quad$ Why was that? ((gesturing to Tianyu))

10 Tianyu I didn't + find an opportunity to join in the conversation

11 Teacher Yeah, and that's normal, especially since you're all

14 Jane You kinda can ask her what she thinks.

15 Teacher Huh?

16 Jane You can ask her what she thinks.

17 Teacher Okay! So if we + if we kinda realize that the that person to join the conversation.

21 Sophie ¿y tú? 
22 Teacher Yeah, ¿y tú?

23 Emmitt ¿Qué creas tú?

24 Teacher Uh huh, so we can invite that person to join us.

In sum, turn allocation in Group 1's performance was dominated by Greg and Frank who implicitly selected each other as next speaker through by expanding a topic that was not relevant to Sophie's participation in the interaction. As a third party, Sophie had to wait for opportunities to proffer a new, relevant topic. The unequal distribution of turns was noticed by the class and discussed in the feedback stage of the DSIS, during which the strategy of asking for a currently nonspeaking party's opinion, as well as two Spanish turn allocation devices, were brought up as resources for distributing turns in a more equal way.

\subsection{Appropriation of a turn allocation device}

Excerpt 3 displays the opening of Group 2's scenario performance (Sophie, Emmitt, and Matt). The reader will recall that two of the group members, Sophie and Emmitt, had offered suggestions for explicitly allocating next turns to nonspeaking parties in the previous feedback discussion. In the excerpt 3 , we observe the deployment of the turn allocation device $i y t u$ ?.

Excerpt 3

1 Sophie ¡Hola! ((saluda al grupo con la mano))

Hi! ((waves at group))

2 Emmitt ¡Hola!

Hi!

3 Matt

¡Hola! [¿Cómo estás?

Hello! [How are you?

4 Emmitt

[¿Cómo estás?

[How are you? 
5 Sophie No muy bien + tengo alergias primaverales.

So, so + I have Spring allergies.

6 Matt Mm.

$\mathrm{Mm}$.

7 Emmitt Sí.

$\mathrm{Oh}$.

8 Sophie ¿tú? ((se dirige a Emmitt))

and you?((turns to Emmit))

9 Emmitt Em + mi no tengo alergias

$U m+I$ don't have any allergies

10

((mueve los hombros hacia arriba)),

((shrugs his shoulders)),

11

$$
\begin{aligned}
& \text { pero }++[\mathrm{em}, \\
& b u t++[u m,
\end{aligned}
$$

12 Matt

[Mm, ¿por qué?

$[\mathrm{Mm}$, why?

13 Emmitt ((mueve la cabeza)) no, no ((risas))

((shakes his head)) no, no ((laughs))

14 Sophie ¿y tú? ((se dirige a Matt))

and you?((turns to Matt))

15 Matt

$$
\begin{aligned}
& \mathrm{Em}+\text { regular + I mean + necesito em + } \\
& U_{m}+\text { so, so + I mean + I need to um }+
\end{aligned}
$$


comprar ropa pero la primavera.

buy clothes for the Spring.

17 Sophie Ah, ven a ver mi casa y comprar de Internet.

Oh, then come over to my place and we can shop online.

18 Matt

Pero es difícil + comprar ropa al internet por em ${ }^{++}$

But it's difficult to + shop for clothes online cause um ++

19

((finge que se prueba ropa)) porque soy muy em

((pretends to be trying on clothes $))$ cause I'm very um

20

alto y etc.? ((risas))

tall and so on? ((laughs))

21

¿y tú? ((se dirige a Emmitt))

and you?((talks to Emmit))

22 Emmitt $[\mathrm{Em}+$

$[U m+$

23 Matt

[ies posible em ir de compras?

[can you um go shopping?

24 Emmitt ¿ir de compras? Em + no tengo em + tiempas or

go shopping? Um + I don't have um + tima or

tiempo a.+ yo tengo + muchas examen y enseyas? ensayos,

time to + I have + lots of tests and essa? essays,

Following an initial greeting sequence (lines 1-4), Sophie opens the topic of spring allergies (line 5). Note that while Matt does respond (line 6), it is Emmitt who picks up the topic with a confirmation in (line 7) and to whom Sophie allocates a next turn 
(line 8), which Emmitt takes up in lines 9-11. Although Matt again attempts to take the floor (line 12), Emmitt continues his turn in line 13. Upon the completion of his turn, which implicitly allocates the next turn to Sophie, Sophie turns to Matt and selects him as the next speaker, using the allocation device iy tú? (line 14). In other words, she offers Matt an opportunity to join the conversation, just as she and others had discussed in the feedback stage of the previous group's DSIS task. Interestingly, Matt also appropriates the iy tú? turn allocation device in line 21, where he selects Emmitt as the next speaker after a multi-turn exchange with Sophie.

During the feedback stage, several students and the teacher noted how Emmitt, Matt, and Sophie allocated turns to each other in a relatively equal way through the use of questions, including the iy tú? tag. In response, the teacher asked the class for other expressions that could be used for the same function (excerpt 4). Note that Sophie offers ¿Qué crees? as a possible turn allocation device (line 4), and the teacher in turn offers several additional resources in Spanish (lines 7-9), thus expanding the potential repertoire on which subsequent groups can draw in their DSISs.

\section{Excerpt 4}

1 Teacher Uh huh, okay, so what are other + other expressions

3 we say? +

4 Sophie ¿Qué crees?

5 Teacher Huh?

6 Sophie ¿Qué crees? What do you think?

7 Teacher Uh huh ¿Qué crees? ((nods)) ¿qué opinas? ¿qué piensas? okay? o ¿te gusta? ¿por qué? This group, any other

9 observations?

\subsection{Expansion of turn allocation repertoires}

We turn now to Group 3's scenario performance. The opening is shown in Excerpt 5, where Elizabet initiates a greeting sequence, which is completed by Adam and Elijah, 
respectively (lines 1-3). In line 4, then, Adam expands the greeting to ask Elijah how he is, and following Elijah's response (line 5), turns to Elizabeth to allocate the next turn to her, using the ¿y tú? tag (line 7). What is interesting about this exchange is that Adam has expanded a typical two-turn question-answer adjacency pair into a four-turn multiparty exchange, thus creating an equal distribution of turns-at-talk (i.e., all parties are included). We note that this creates a context in which Elijah can in turn self-select to begin speaking (line 15), and who subsequently continues to engage in multiparty interaction in line 20 where he explicitly addresses both Adam and Elizabeth.

\section{Excerpt 5}

1 Elizabeth ¡Hola, amigos!

Hi friends!

2 Adam ¡Hola, amigos!

Hi friends!

3 Elijah ¡Hola!

Hi!

4 Adam ¿Cómo estás?

How are you?

5 Elijah Así, así ((sacude la mano derecha)) em + mi + or

So, so ((shakes his right hand)) um + me + or

6

yo tengo + ale alergias.

I have + ale allergies.

7 Adam

Ah, sí, ¿y tú? ((se dirige a Elizabeth))

Oh, I see. And you? ((turns to Elizabeth))

8 Elizabeth $\quad$ Em + me gusta el tiem tiempos? em +

$U_{m}+$ I like the wea weather? um + 
9

yo quiero ir de compras?

I want to go shopping?

10 Adam

Ah, sí ((mira a la ventana)) + es muy fresco,

Oh, yeah ((looks at the the window $))+i t$ 's nice

11

es primavera, pero em + no em + no puedo ir de compras

it's Spring, but um + I can't um + can't go shopping

12

porque tengo tarea y mucho em + trabaje.

because I have a lot of homework and a lot of um + work.

13 Elizabeth Oh, lo siento ((risas)).

Oh, I'm sorry ((laughs)).

14 Adam Sí,

Yeah,

15 Elijah ¿Qué clases?

For which classes?

16 Adam Em hay un examen de español esta semana +, so,

Um we have a Spanish test this week + , so,

17 Elijah [Sí,

[Yeah,

18 Elizabeth [Sí,

[Yeah,

19 Elizabeth [Em,

$[U m$, 
20 Elijah [Puedos em puedes vamos a mi casa y em tú trabajas

[We um we can go to my place and um you can work

21

$$
\text { ((señala a Adam)) y tú comprar ((señala a Elizabeth)) y, }
$$

((points to Adam)) and you shop online ((points to Elizabeth)) and,

22 Elizabeth [Em,

$$
[U m,
$$

23 Elijah [no vamos afuera?

[we don't go outside?

24 Adam

$\mathrm{Em}+$ pero + la biblioteca tiene los cosas que

$U m+$ but + the library has everything I

ayúdame em + para estudiar,

need um + to study,

26 Em hay computadores para ir de compras, de hecho.

Um there are even computers to shop from, in fact.

A final example is given in excerpt 6 . Here, the interaction primarily involves Adam and Elizabeth at the outset (lines 44-49). In line 49, Elizabeth makes a suggestion to study now and go shopping at the weekend, which is directed at Adam. However, rather than responding immediately to Elizabeth, which is Adam's right having had the turn allocated to him, he turns to Elijah and solicits his opinion with the ique + crees? turn allocation device (line 50). In other words, Adam has continued to use the expanded range of turn allocation devices that emerged from the series of DSISs in order to facilitate a relatively equal distribution of turns in this multiparty interaction.

Excerpt 6

44 Adam Por el fin de semana + ir de compras, pero estudia +

On the weekend + we go shopping, but we stud + 
estudiamos para el [examen, study for [the test,

46 Elizabeth

$$
[((\text { asiente })) \text { bien. }
$$

$$
[(\text { nods })) \text { good. }
$$

47 Elijah

$$
[((\text { asiente) })
$$

$$
[((\text { nods }))
$$

48 Adam

esta semana?

this week?

49 Elizabeth em, sí, em + vamos en fin de semana + ahora estudiamos?

um, yeah, um + let's go shopping on the weekend + and study now?

50 Adam

¿qué + crees? ((se dirige a Elijah)

what do you think? ((turns to Elijah))

51 Elijah Em, lo siento, repito tu pre, +

Um, I'm sorry, repeat your que, +

52 Adam

¿Por la fin de semana + te quieres ir de compras y

Do you + want to go shopping over the weekend

53

por esta semana estudio? estudiamos?

and stud + study over the week?

54 Elijah Sí.

Okay.

55 Elizabeth Sí.

Okay. 


\section{Discussion}

In this article, we have reported findings of an initial attempt at enhancing the development of interactional repertoires (Hall, 2018) through DSISs, with specific focus on turn allocation practices. In our approach to implementing DSISs into the classroom, feedback discussions were sandwiched between performances in an attempt to make feedback from the teacher as well as from other students available to subsequent groups. As we have shown, turn allocation in the first group's performance emerged as a focus of their feedback discussion because the class noticed that one of the group members had been left out of the interaction. Subsequent groups were in turn able to make use of and expand on the proposed practices for allocating turns in a more equal way (i.e., including all parties) in their performances, which we see as evidence of development. In what follows, we discuss our findings and their implications for research and pedagogy as well as some of the limitations of and future directions for our work on DSISs.

\subsection{Mediating the expansion of interactional repertoires}

As noted, our study aligns with and extends recent work examining pedagogical arrangements aiming to expand L2 learners' interactional repertoires (e.g., BarrajaRohan, 2011; Kunitz \& Yeh, 2019; Lilja \& Piirainen-Marsh, 2019; Waring, 2019). We have focused specifically on the way in which DSIS tasks may create space for reflecting on interactional phenomena, specifically turn allocation, and raising learners' awareness of the resources available for use. As we illustrated in the analysis, focus on turn allocation practices emerged first during the feedback session on Group 1 's scenario performance when a student audience member commented that one of the three group members seemed to be left out. The teacher in turn led the class in a brief discussion of strategies for distributing turns more equally in multiparty interactions. These strategies were picked up and further expanded in subsequent group performances and feedback sessions.

The major theme that emerges in this analysis is the role of the feedback session as a form of mediation (van Compernolle, 2018) leading to the expansion of learners' interactional repertoires. By mediation, we refer to Vygotsky's (1978) observation that development (i.e., the internalization of cultural tools) is supported by more experienced or competent people in one's environment who can direct and guide one's use of relevant tools. In L2 educational settings, this form of human mediation occurs in interactions in which a teacher, and possibly other learners (Donato, 1994), assist a learner in becoming aware of and using a relevant L2 resource. In other words, distinct form concepts like scaffolding and assisted performance, the notion of human 
mediation focuses on the guided appropriation of a recontextualizable resource, not simply help with performance on a specific task (van Compernolle, 2015).

In the present study, mediation helped to raise learners' awareness of turn allocation as something to pay attention to during interaction as well as their awareness of some common turn allocation devices in Spanish, which they were able to put into practice in subsequent scenario performances. We believe that the proximity of mediation to performances was especially important. Since feedback sessions immediately followed performances, the class was able to reflect on and evaluate the performance while it was still fresh in their minds. In turn, the next group was able to perform their scenario shortly after the feedback session of the prior group, giving them an immediate opportunity to put into practice the suggestions that had been offered.

While our study suggests that the immediacy of mediation is an important dimension of DSIS tasks, it remains an empirical question whether, or to what extent, some delay between feedback and a next performance may impact on its effectiveness. The class we worked with was relatively small, and it was possible to have all groups perform and receive feedback in the same 50-minute class meeting. However, we recognize that such arrangements may not always be feasible, especially at larger institutions where class sizes often reach 20 students or more. In such cases, it may not be possible for all groups to perform on the same day. Teachers may therefore need to carry out DSIS tasks over multiple class meetings (i.e., all students perform over 2-3 class meetings), or alternatively to allow only a subset of students to perform each scenario. The latter suggestion would involve 2-3 small groups performing each scenario in a single class meeting, while other students would act as audience members and provide feedback. Ideally, DSISs would be performed multiple times during a term so that all students have the opportunity to perform at least one scenario. Future research would do well to examine these various arrangements of scenario performances and feedback sessions to determine the extent to which DSISs are feasible in larger classes or in courses.

\subsection{The potential contribution of task repetition}

It follows from the discussion of mediation in the previous section that task repetition may be one of the key strengths of our approach to using DSISs. Indeed, research in task-based language teaching supports the idea that task repetition (Bygate, 2018), or multiple iterations of a task (Larsen-Freeman, 2018), can benefit learners' performances over time. The contribution of task repetition in this research is typically explained in terms of reducing the cognitive burden of learners as they become more 
familiar with the task such that they become more capable of producing increasingly complex, accurate, and/or fluent speech.

Our study is somewhat different from the cognitivist approaches to task repetition noted above in two important ways. The first difference is that the scenario performances were repeated by different groups of learners rather than by the same individuals. The second difference is that a debriefing phase in which feedback was provided was inserted between each scenario performance. Together, these two differences compel us to take a somewhat different stance toward task repetition than in previous literature, one that focuses not on the individual but on the class acting as a collective unit. Indeed, such a view aligns with Vygotskian theory and the notion of a group zone of proximal development (ZPD) that may emerge through collectivization (Petrovsky, 1985; Poehner, 2009). In this view, a group is not simply a context in which individuals act, but a collective in which individuals act "for others as for oneself" (Petrovsky, p. 191) in pursuit of the group's collective development.

Taking a group-as-collective perspective, we can see how the repetition of the scenarios by different groups and the group feedback sessions in between each performance may function as a collectivizing activity. For example, while only one group performs at a time, other members of the class are tasked with watching and evaluating the performance so that they can provide constructive feedback following the performance. This feedback session, as we have seen, serves not only to evaluate the group who has just performed, but to set the stage for the next group's iteration of the task that may incorporate the feedback and build on the prior performance. In a sense, the performances themselves are less about the individual students who happen to be performing and more about putting into practice the interactional repertoire the class is developing as a collective. Therefore, DSIS repetitions push the group's development forward, and this has the potential to benefit each individual even if they may not be current performers or direct recipients of feedback.

It should be noted that while we believe the group-as-collective perspective is useful for describing our approach to DSIS tasks, we acknowledge that our data do not allow us to assess the develop of each individual within the group. In other words, our data suggest that collectivization processes can have a beneficial impact on individuals, but we are unable to demonstrate that every member of the class learned or developed as a result of the DSIS tasks. As we continue working through our data set, we are certainly considering whether there is evidence that other students who happened not to speak during the tasks analyzed in this article expanded their interactional repertoires of turn-allocation practices. Future research should also consider developing methods for linking group and individual development over time, as discussed in the next subsection. 


\subsection{Tracking development over time}

Our study has focused on what we consider to be the microgenesis of an expansion of students' interactional repertoires during a single class meeting involving three iterations of a DSIS. As noted, we have suggested the central role of the feedback session as mediation and the contribution of task repetition within the collective activity of the class. However, it is not clear whether, and to what extent, the potential developmental processes documented in the analysis led to growth over a longer time frame. Indeed, we would hope that DSIS tasks support learners in expanding their interactional repertoires in ways that transcend the tasks themselves so that learners become increasingly able to recontextualize the new resources they have appropriated over time. In future, we see tracking development over time as a two-part undertaking.

The first would involve tracking learners' interactional repertoires across multiple DSIS task sessions (e.g., spaced several weeks apart). Doing so would provide researchers as well as teachers specific data points for documenting students' use of relevant interactive practices as well as the opportunity to push learners by introducing more complex situations. Taking turn allocation practices as an example, we might consider designing scenarios in which next speaker selection is more complicated than a multiparty interaction among friends. For instance, introducing a unequal power dynamic in which power relations could push students to consider the ways in which power relations may be enacted through the allocation of turns as well as how and when one might self-select as next speaker as a means of challenging such a power dynamic. In other words, the point of subsequent scenarios would not be to continue to practice and expand turn allocation devices but to critically reflect on the sociopragmatic meaning and significance of turn taking and next speaker selection.

The second approach to tracking development over time would involve expanding the evidential basis beyond DSIS tasks. In classroom settings, this would primarily involve documenting students' deployment of newly appropriated interactive practices in other forms of classroom interaction. For example, the expansion of turn allocation repertoires could lead to a diversification of classroom interaction patterns in which students move out of the ubiquitous practice of Initiation-Response-Feedback (Lee, 2007; Sert, 2015; Waring, 2009). This is important because recent research has suggested that when students self-select to expand or proffer new topics and allocate turns to one another rather than always responding directly to the teacher may lead to a richer environment for learning (Adams \& van Compernolle, 2019; Dolce, 2019; Dolce \& van Compernolle, 2019; Waring, 2009). In other words, not only would we be interested in documenting the expansion of learners' interactional repertoires over time but also in documenting the consequences of learners' expanded repertoires for conducting the institutional business of teaching and learning in the classroom. 


\section{Conclusion}

In this article, we have reported on the implementation of dynamic strategic interaction scenario tasks in an elementary-level US university Spanish classroom. We focused specifically on the development of turn allocation resources as part of learners' interactional repertoires (Hall, 2018). Our data suggest that the multiple iterations of the DSISs, including feedback sessions after each performance, mediated students' appropriation of relevant turn allocation practices, which they were in turn able to use in subsequent iterations of the scenario. We have also suggested that task repetition, from the perspective of the group-as-collective (Petrovsky, 1986; Poehner, 2009), was central to the microgenetic processes we observed. We are hopeful that our study can serve as a starting point for future research into the use of DSIS tasks for organizing pedagogical arrangements for the development of learners' interactional repertoires.

\section{References}

American Council on the Teaching of Foreign Languages [ACTFL]. (2012). ACTFL proficiency guidelines 2012. Fairfax, VA: American Council on the Teaching of Foreign Languages. Available at https://www.actfl.org/publications/guidelines-andmanuals/actfl-proficiency-guidelines-2012

Adams, A., \& van Compernolle, R. A. (2019). Beyond lecture-advancing responses: Knowledge imbalances and opportunities for learning in an advanced Hispanic Studies classroom. Unpublished manuscript.

Bachman, L. F. (1990). Fundamental considerations in language testing. Oxford: Oxford University Press.

Barraja-Rohan, A. M. (2011). Using conversation analysis in the second language classroom to teach interactional competence. Language Teaching Research, 15(4), 479-507.

Bygate, M. (Ed.). (2018). Learning language through task repetition. Amsterdam: John Benjamins Publishing Company.

Canale, M. \& Swain, M. (1980). Theoretical bases of communicative approaches to second language teaching and testing. Applied Linguistics, 1, 1-47.

Celce-Murcia, M. (2007). Rethinking the role of communicative competence in language teaching. In E. Alcón Soler \& M.P. Safont Jordà (Eds.), Intercultural language use and language learning (pp. 41-57). Berlin: Springer.

Celce-Murcia, M., Dornyei, Z., \& Thurrell, S. (1995). Communicative competence: A pedagogically motivated model with content specification. Issues in Applied Linguistics, $6,5-35$. 
Di Pietro, R. J. (1987). Strategic interaction: Learning languages through scenarios. Cambridge: Cambridge University Press.

Dolce, F. M. (2019). Expanding discourse options in the foreign language classroom: Teaching turn-taking norms to enhance interactional competence in an advanced Mandarin class. PhD thesis, Carnegie Mellon University. Pittsburgh, PA.

Dolce, F. M., \& van Compernolle, R. A. (in press). Topic management and student initiation in an advanced Chinese-as-a-foreign-language classroom. Classroom Discourse.

Hall, J. K. (1993). The role of oral practices in the accomplishment of our everyday lives: The sociocultural dimension of interaction with implications for the learning of another language. Applied Linguistics, 14, 145-167.

Hall, J. K. (1995). "Aw, man, where we goin?" Classroom interaction and the development of L2 interactional competence. Issues in Applied Linguistics, 6, 37-62.

Hall, J. K. (2018). From interactional competence to interactional repertoires: Reconceptualizing the goal of L2 learning, Classroom Discourse, 9, 25-39.

Hall, J. K., Hellermann, J., \& Pekarak Doehler, S. (Eds.). (2011). L2 interactional competence and development. Clevedon: Multilingual Matters

He, A. W., \& Young, R. (1998). Language proficiency interviews: A discourse approach. In R. Young \& A. W. He (Eds.), Talking and testing: Discourse approaches to the assessment of oral proficiency (pp. 1-24). Amsterdam: John Benjamins.

Kramsch, C. (1986). From language proficiency to interactional competence. Modern Language Journal, 70, 366-372.

Kunitz, S., \& Ye, M. (2019). Instructed L2 interactional competence in the first year. In M. R. Salaberry \& S. Kunitz (Eds.), Teaching and testing L2 interactional competence: bridging theory and practice (pp. 228-259). New York: Routledge.

Larsen-Freeman, D. (2018). Task repetition or task iteration? It does make a difference. In M. Bygate (Ed.), Learning language through task repetition (pp. 311-330). Amsterdam: John Benjamins.

Lee, Y. A. (2007). Third turn position in teacher talk: Contingency and the work of teaching. Journal of pragmatics, 39(6), 1204-1230.

Lilja, N., \& Piirainen-Marsh, A. (2019). Making sense of interactional trouble through mobile-supported sharing activities. In M. R. Salaberry \& S. Kunitz (Eds.), Teaching and testing L2 interactional competence: bridging theory and practice (pp. 260-288). New York: Routledge.

Petrovsky, A. V. (1985). Studies in psychology: The collective and the individual. Moscow: Progress Publishers. 
Poehner, M. E. (2008). Dynamic assessment: A Vygotskian approach to understanding and promoting second language development. Berlin: Springer Publishing.

Poehner, M. E. (2009). Group dynamic assessment: Mediation for the L2 classroom. TESOL Quarterly, 43, 471-491.

Sacks, H., Schegloff, E. A., \& Jefferson, G. (1974). A simplest systematics for the organization of turn-taking for conversation. Language, 50, 696-735.

Salaberry, R., \& Kunitz, S. (Eds.). (2019). Teaching and testing L2 interactional competence: Bridging theory and practice. New York: Routledge.

Schegloff, E. A. (2007). Sequence organization in interaction: A primer in conversation analysis I (Vol. 1). Cambridge, UK: Cambridge University Press.

Sert, O. (2015). Social interaction and L2 classroom discourse. Edinburgh: Edinburgh University Press.

Sidnell, J. (2010). Conversation analysis: An introduction. West Sussex, UK: WileyBlackwell

van Compernolle, R. A. (2014a). Sociocultural theory and L2 instructional pragmatics. Bristol: Multilingual Matters.

van Compernolle, R. A. (2014b). Profiling second language sociolinguistic development through dynamically administered strategic interaction scenarios. Language and Communication, 37, 86-99.

van Compernolle, R. A. (2015). Interaction and second language development: A Vygotskian perspective. Amsterdam/Philadelphia: John Benjamins.

van Compernolle, R. A. (2018). Focus on meaning and form: A Vygotskian perspective on task and pragmatic development in dynamic strategic interaction scenarios. In M. Ahmadian \& M. P. G. Mayo (Eds.), Recent trends in task-based language learning and teaching (pp. 79-97). Berlin: Mouton De Gruyter.

Vygotsky, L. S. (1978). Mind in society: The development of higher psychological processes. Cambridge, MA: Harvard University Press.

Waring, H. Z. (2009). Moving out of IRF (Initiation』Response』Feedback): A single case analysis. Language Learning, 59, 796-824.

Waring, H. Z. (2018). Teaching L2 interactional competence: Problems and possibilities. Classroom Discourse, 9, 57-67.

Waring, H. Z. (2019). Developing interactional competence with limited linguistic resources. In M. R. Salaberry \& S. Kunitz (Eds.), Teaching and testing L2 interactional competence: Bridging theory and practice (pp. 215-227). New York: Routledge. 
Young, R. F. (2008). Language and interaction: An advanced resource book. New York: Routledge.

\section{Appendices}

\section{Appendix A. Activity 1}

NB: A list of expressions had already been distributed for the first scenario. Subsequent DSIS preparations built on the linguistic and interactional resources.

Do some research online and add 3 new expressions to the list. For each expression, consider the following questions: What category does it belong to? What is its function? Is it formal/informal? Is it used in a specific Spanish-speaking country?

\begin{tabular}{|l|l|l|l|l|l|}
\hline $\begin{array}{l}\text { Seeking help/ } \\
\text { repetition }\end{array}$ & $\begin{array}{l}\text { Showing } \\
\text { courtesy }\end{array}$ & $\begin{array}{l}\text { Expressing } \\
\text { doubt }\end{array}$ & $\begin{array}{l}\text { Agreeing/ } \\
\text { giving } \\
\text { approval }\end{array}$ & Disagreeing & $\begin{array}{l}\text { Making } \\
\text { suggestions }\end{array}$ \\
\hline & & & & & \\
\hline
\end{tabular}

\section{Appendix B. Scenario description}

NB: Spring A, B, and C refer to the roles for individual students. Each student received only one role description for each DSIS. We have simply compiled them here so the reader can see what all the roles were for this scenario. DSISs were adapted or inspired by scenarios compiled by Matthews (n.d.), available here: http://faculty. weber.edu/tmathews/ScenarioCollection.pdf

Topics: Leisure plans, recreation, shopping

Roles: Friends

Notions/Functions: Convincing, describing

SPRING A: Spring is finally here. You wish you could be outdoors and go on adventures, but you can't because of your Spring allergies. Invite your friends over to do something fun at your place. 
SPRING B: Spring is finally here. You wish you could be outdoors and go on adventures, but you don't have time for that during the end of the semester. You have schoolwork to do and important deadlines coming up. Tell your friends what you're working on and convince them to get together to study/work/go to the library.

SPRING C: Spring is here, and you couldn't be more excited about the good weather. You can't wait to be outdoors and go on adventures, but you don't have good clothes for that. You really want to go to the shopping mall to buy sports clothes. Tell your friends about all the activities you want to do, the stores you want to go to, and convince them to come along.

\section{Appendix C. Activity 2.}

Come up with a plan and useful language for convincing your friends in the scenario to do what you want to do. Think about strategies or ways to make suggestions, offer alternatives, agree/disagree with other plans, etc. You will have a chance on Tuesday to discuss and share ideas with other classmates who are going to play the same role.

\begin{tabular}{|l|l|l|l|}
\hline Useful expressions & Useful vocabulary & Useful grammar & Main arguments \\
\hline & & & \\
& & & \\
\hline
\end{tabular}

\section{Appendix D. Transcription conventions (adapted from van Compernolle,} 2014)

$+\quad$ short pause

$+\quad$ long pause

. full stop marks falling intonation

, slightly rising intonation

? $\quad$ raised intonation (not necessarily a question) 
A study of $L 2$ vocabulary acquisition under incidental and intentional conditions

$(($ comment $))$ double parentheses contain transcriber's comments or descriptions underline underlining indicates stress through pitch or amplitude

[ onset of overlapping speech

CAPITALS capital letters indicate markedly loud speech 
